\title{
E- MIGRANT: TECHNOLOGICAL, GEOGRAPHICAL AND SOCIAL SPACES. NEW ACTORS AND SPACES FOR POLITICAL PARTICIPATION?
}

\author{
Mauricio Nihil Olivera
}

\begin{abstract}
This article is based on the results provided by the research project named "A study of recent migratory movement from Spain to Uruguay. New technological, geographical and social spaces for citizen vincluation" (Olivera et al., 2014) and, by using the concept of "e-migrant", it analyses if the introduction of ICTs enables the renewal of the traditional forms of political participation and public decision-making. Having the concept of e-migration as a starting point, the article aims at identifying what are the forms and the type of communication networks used by the new Spanish migrants as well as the way they connect and communicate (politically, socially and culturally) in Uruguay. It also aims at problematizing these issues under the light of the Social Sciences theories, following the critical investigative line of research about the "Information Society". The authors argue that the ways new Spanish migrants connect to each other in Uruguay are dialectic relationships and are also a result of a social process that depends on the decisions and on the significances given by individuals. These decisions and subjectivities are not determined solely by the structures that are inherent to their condition as migrants, neither are they totally contingent to this condition; they move in a space of possible configurations in order to be re-signified in concrete situations.
\end{abstract}

\section{Keywords}

Technological, geographical and social space; e-migrant; Uruguay; information and communication technologies; citizen participation

\section{INTRODUCTION}

Can the combination between information and communications technologies (ICT), new social communicational dynamics, as well as the desire and interest of Spanish migrants in participating in the governance process generate new spaces for collaboration that might renew or change the traditional forms of political participation and public decision-making? Is it possible to think about the co-definition of a new form of participative engineering that could possibly adopt, adapt and enrich a new form of political organisation, that is, an e-democracy? Is it possible to propose the existence of a space for innovation inside which new modes of relationships between states and their citizens could circulate?

As discussed in another paper (Olivera et al., 2014), questions have lead us to observe, in the present work, if the emergence and development of ICTs may imply important alterations regarding the construction of a new political and social contract as opposed to more classical forms of politics and of the political decision-making process, expressed in the configuration of new Technical, Geographical and Social structure (TCS). 
In this article, we not only dedicate ourselves to the questions above mentioned, but we also pay particular attention to social and technological practices of the more recent group of Spanish immigrants in Uruguay. We think about this group as new actors that are connected and who interact and intersect with different logics and temporalities (the e-migrants), new social forms which reflect the relationship with time, space and place generating, at the same time, other phenomena of integration and exclusion, as well as of de-territorialisation and relocation.

Afterwards, we develop the proposed concept of e-migrant within the configuration of a new Technological, Geographical and Social Space (Olivera \& Vancea, 2013; Olivera, 2011; 2013a; 2013b; 2013c). Consecutively, we describe the methodology as well as the results provided by the study "Recent migratory movement from Spain to Uruguay", which was carried out by the "Polo Mercosur" foundation, funded by the Spanish Migrations Directorate. Finally, in the section called "discussions", we dissert about some of the limitations and conceptual objections.

\section{E-MIGRANTS. A NEW CONFIGURATION OF TECHNOLOGICAL, GEOGRAPHICAL AND SOCIAL SPACE}

Following the critical investigative line about Information Society (Becerra, 2003; Mattelart, 2003, 2007; Webster, 2006; Tremblay \& Gaëtan, 2003) the purpose of this section is to present a theoretical discussion to what we term as "Technological, Geographic and Social Spaces" (TGS). We refer to new spaces through which e-migration circulates and in which ICTs are only one of the dimensions. The theoretical framework suggested by the concept of e-migration is just an attempt to rethink the creation of significant units of analysis for further researching within the areas of communication and public policies within the field of international migration.

Today, cities are crossed and configured by TCS spaces - spaces where people coming from multiple geographic origins, ideologies and cultures coexist and generate collective and individual scenarios of living (Olivera, 2014). The attention given to deep transformations concerning the ways of understanding the space/time relationships also implies understanding the deep changes occurring within the human experience (Cruz, 2007). The words "geographical" and "social" correspond to concepts people have about the world and are used in everyday life, as well as in scientific practices to guide, highlight, differentiate and reduce the complexity during the process of attributing meaning to different phenomena. There is a dialectic connection between both: the social dimension does not exist anymore without a geographical dimension and vice versa.

What we name as "technological" crosses both the geographical and the social dimensions, allowing the existence of new logics and forms of production, circulation and of informational appropriation in a context of continuous and speedy technological change. Presently, ICTs allow diverse social actors to develop new practices and logics of participation that are configured by new and multiple relationships between space, time and place. These technological innovations are in the core of the emergence of other 
collaborative strategies and logics, as well as of participation and interchange between social actors. The TGS spaces are mediated by socio-cultural practices, as well as by other dimensions such as distance, territory and identity(ies).

The TGS spaces are knots, spaces into which parts of other connections belonging to other spaces - real or abstract but sharing the same trait - converge. A network may be defined as a "matrix of interconnected nodes", whereas a node is the point where a curve intersects with itself (Castells, 1997, p. 56). These TCS spaces are key grounds to observe both new technosociabilities and new emerging and spreading relations between social actors, as well as their technological practices through which meanings and identity values become expressed. The Internet is committed to an important function insofar as it is the tool that facilitates these relationships. The complex relationships between distances, territories and identities are guiding the circulation of social practices within the TGS. The methodological problem lies, then, in the observation and analysis of the way these practices are constituted within Technological, Geographical and Social relationships that take place in the Internet.

TGS spaces allow the reconfiguration of connective and collective flows within a technological change context. For instance, nowadays, mobile phones allow for a global connectivity through satellite communications. Those technological innovations generate specific logics and strategies of collaboration, participation and interchange between actors, thus establishing new transnational spaces that require the revision - within receiving countries as well as within the own theoretical scientific field of international migrations - of traditional concepts such as "migrant", "immigrant", "integration", "assimilation", and so on. Being true that transnational processes had already existed long before the twentieth century (Portes et al., 1999; Schnapper, 2001; Vertovec, 1999), the coming of the digital age has marked the beginning of a new phase of qualitative changes (Beck, 2006; Castells, 2004; Nedelcu, 2009; Vertovec, 2009).

In this new TGS space, ICTs and Internet have an important role. The e-migrant is thought as a nomad who is connected to a device such as a mobile phone, and that builds transnational relations. Following this line of thought, De Kerckhove (2005) argues that globalisation reaches us all, even those without Internet or mobile phones (Olivera, 2011). Other authors agree with the existence of new virtual or actual territorialities. In these spaces, ICTs could give place to a process of "technosociabilities" which would affect migrants mostly concerning the development of new forms of cultural, political and social interaction as well as new forms of transnational, global and virtual communication (Bernal, 2004; Escobar, 2000; Gómez Cruz, 2003; Graham \& Marvin, 2001; Rheingold, 1996). Diminescu (2008), who was in charge for the research project: "Diasporas on the Internet: E-Diaspora Atlas", also understands that virtual spaces could be generating a "development of networks, activities, lifestyles and ideologies which constitute a link between sending country and receiving country and that re-presents mobility" (p. 567).

Some researchers argue that the increasing mobility that permeates present day lifestyles - "being together at a distance" - would seriously put into question the limits of territoriality as a category to think about multicultural identities, transnational social 
practices and cosmopolitan "belonging" (Beck, 2003, 2006; Beck \& Grande, 2010; Beck \& Sznaider, 2006; Benhabib, 2004; Chang, 2010; Georgiou, 2010; Maharaj, 2010). This argument suggests that the emergence of new forms of socialization and identification yet incipient, within the global media arena, would start with a de-territorialisation process (Olivera, 2013c).

Transnational social practices can be highlighted by the growing intensity of global interchanges, as well as by the activities and omnipresent system of communication which allows migrants to be connected to multiple worlds, geographically distant and culturally different from their own (Nedelcu, 2010; Vertovec, 2009). These new practices and social logics of participation, co-operation and interchange between those actors reconfigure the relationships between space-time and place, as well as between public and private.

In sum, in these new configurations there are technical, geographical and social spaces in which e-migrants have surpassed the limits of space and time, thanks to the intervention of ICTs and of the Internet. The term e-migrant, then, permits the dialectical articulation of the relationship between migrants and their integration into the multiple technological, social and spatial dimensions in the Information Society. Present day migratory process, thanks to ICTs, cannot escape from, nor not include, the technological dimension, the geographical and social space between countries of origin and countries of destination. On the other hand, if migration is analysed as a process of continual movement which opens into interactions, interconnection, virtuality, convergences and ubiquities, then the idea of "leaving" or "entering" a virtual social space, on these terms, seems at the least debatable (Olivera, 2013a, 2013b, 2013c).

For example, the new Spanish e-migrants in Uruguay who participate in the virtual platforms "Marea Granate"1 and "Alianza" ${ }^{2}$ are a clear example of how TGS spaces enable the visualisation of the views of "the many others" and the reconfiguration of fight for the public space, utilizing the web to generate "noise" and distortion in the discussion of "globality". These Spanish e-migrants also construct groups that, while virtual at birth, can end up territorialising themselves, going from a virtual connection to an encounter and from an encounter to action. For some authors, (Kroes, 2000; Finquelievich, 2000; Molina, 2001) the alternative use of the web and IT technologies in the reconstruction of the public sphere is connected to profound changes in mental maps and positions, in

\footnotetext{
"Marea Granate is a transnational nonpartisan collective formed by immigrants from the Spanish State and sympathisers whose aim is to fight against the causes and people who have provoked the economic and social crises that force us to emigrate". This presentation can be found in the following website: http://mareagranate.org/. This organisation was brought into existence on April 7, 2013, after a manifestation under the slogan "We are not leaving, we are being thrown out," convened by Juventud Sin Futuro, all over the world. On their website they say: "We have not come to Montevideo: they have thrown us out of Spain, and our goal is to support the assemblies, nodes, groups and tides fighting to avoid that the $1 \%$ gets away with it. We have two main missions: a) preventing any information that comes to Uruguay about Spain through government propaganda channels; and b) supporting each other so that the migration experience is as smooth as possible. We meet every other Sunday in open meetings that we announce in the Facebook group and on Twitter: we are waiting for you with open arms and a cup of Mate".

${ }^{2}$ It is an open space for youth participation that focuses its activities on the educational, cultural, social and human development aspects, pointing out that they are a tool for development and realisation of projects of young people. They consider themselves as "apolitical" and claim to fully represent the Uruguayan Hispanic youth at national, regional and international levels. "Alianza" (Alliance) presentation: https://www.linkedin.com/groups/ ALIANZA-J\%C3\%B3venes-Espa\%C3\%B1oles-Descendientes-Uruguay-4240829/about.
} 
the languages and the designs of public policies. All these dimensions are mediated by the TGS reconfigurations.

Hence, the e-migrant perspective opens new routes for the study of international migration in the digital era. It is an alternative avenue to obtaining a new understanding of the actions that take place in those spaces; it widens the view on this issue beyond countries of origin and reception, re-articulating dichotomies such as: insider/outsider, nomad/sedentary, national/ trans/national, virtual/ present, on line/off line etc. The observation of international migration through the e-migrant perspective also grants a better comprehension of the identity negotiations and tensions that occur in different and diverse sociocultural systems.

This perspective also grasps the more deep transformations spawned in the social, political and economical life of migrants, interpreting social changes as new organization of the social spaces, generated by the new technologies. The utilisation of this concept also allows us to observe the way in which ICTs are capable of transforming the significance of geographical distance, citizenship, public space, identity and social ties. Furthermore, this conceptualization admits the analysis of the transnational practices related to social integration, social and political representation, political, economical and cultural participation, subjectivity, social order, social imaginary etc.

The proposed concept of the e-migrant permits the idea of a new space from which innovative forms of the relationship between a state and its citizens could evolve. Many e-migrants, like the ones that are part of "Marea Granate" and "Alianza", demand recognition stemming from the right to participate (by intervening in the decisions that affect their quality of life and their relationship with the administration), and the right to express themselves (related to the participation of citizens in the media). Such demands show that e-migrants seek new ways to exercise their political rights, with more flexible and mobile loyalties, and, thereupon, with the existence of more open political groups.

\section{Methodology}

The research project "Study of the recent migratory movements from Spain to Uruguay..." entails the strategic design of a methodological triangulation that considers different perspectives of the same subject. The methodological techniques applied can be justified by the specific objectives of the investigation, namely: 1) the establishment of a quantitative estimative and of a recent mobility map of the Spanish migrants in Uruguay; 2) the elaboration of a sociodemographic typology of the Spanish residents in Uruguay; 3) the identification of the long distance communication networks used by the aforementioned migrants. Due to space reasons, this article only scrutinizes the results derived of objective 3 .

In order to draw results from objectives 1 and 2 the following quantitative techniques were used: self-administered questionnaire conducted via web, answered by Spanish migrants who arrived in Uruguay from 2008; statistical analysis of micro data provided by the National Institute of Statistics of Uruguay (NE) and derived from the 
National Census conducted in 2011; and statistical analysis of the data supplied by the National Statistics Institute of Spain, which is available on the internet. The analysis, regarding objective, 3 was carried out with the following quantitative techniques: focus group and workshops. Three focus groups and one workshop with Spanish immigrants arrived since 2008 were organized and, in the workshops, both the Spanish administration and the collectives that form the Spanish societies in Uruguay were represented.

The statistical universe of the migrant Spanish population living in Uruguay is comprised of: a) individuals between 25 and 45 years of age (that is, individuals that belong to the economically active population); b) of both sexes; c) born in Spain (those of Spanish nationality were excluded); d) those that migrated from 2008 onward - without taking into consideration their having registered as emigrants at the Spanish consulate -; e) individuals that live in the capital of Uruguay (Montevideo); and f) that are users of the ICTs ${ }^{3}$.

\section{FOCUS GROUPS: DATA COLLECTION}

The purpose of the discussion groups was to reconstruct the social relationships that underlay the actual numerical measuring process, thus unravelling the processes and constructions that are part of a narrative identity. The usage of this technique allowed an approximation to the behaviour of the group and an understanding of their motivations. Moreover, with this qualitative methodology, it was possible to understand the type of discourse sustained by the group and, therefore, the position of the Spanish migrant collective regarding the practices of the 'ICTs', as well as the idea of "migratory management". We seek to highlight, based on the ICTs, the cultural and communicational dimensions that line off those individual's social life, as well as analyse the scope and the way the intervention of technology acquires a significant role (or not) in their social, political and labour relations, by observing their opinions and contradictions. While dealing with the issues of migratory projects and the aforestated constructions we have dedicated a special interest to the use migrants make of ICTs and what connections they maintain between their country of destination and their country of origin. The discussion group also analysed if the intervention and use of ICTs had changed - and if so how these people's social communication practices. The type of information they search for in their country of origin was also emphasized as were the media consulted.

The participants of the focus groups were initially chosen from facilitators of the virtual platforms for Spanish migrants "Marea Granate" and "Alianza". There was greater willingness from the members of "Marea Granate" to participate in the focus groups. However, this choice did not yield the expected results: only two or three individuals out of an assembly of twelve were part of the "Marea Granante" collective. For this reason, it was decided to search for participants in different virtual platforms and by word of mouth. This new selection, while permitting a more eclectic group, did not facilitate a

${ }^{3}$ The total number of Spanish immigrants in Uruguay is 12,676. 80.5\% is located in the department of Montevideo (Koolhas \& Nathan, 2013), according to the 2011 Census. Of this total, 1478 are migrants that arrived in Uruguay from 2008 and $55.4 \%$ of them live in Montevideo. Spaniards are the most important European immigrant collective in Uruguay and particularly in Montevideo. 
quick shaping and forming of relationships of trust and confidence between the participants. The interviewer acted as moderator of the group, trying to intervene as little as possible in the debates, but introducing relevant topics when sufficient information was generated on each topic in turn. The individuals in the group were not previously acquainted with the interviewer.

The group of Spaniards resident in Uruguay was brought together in June 2014, and had a total of twelve members. Three different meetings took place, due to scheduling difficulties. The job insecurity of members and, in some cases, different working hours, were instrumental at the time to organize the discussion sessions. The following criteria were taken into account in the selection of the sample:

1. Arrival of individuals in Uruguay (they had to have arrived in Uruguay between 2008 and 2014);

2. Age of the participants (they had to be between 25 and 45 );

3. Equal gender representation within the group;

4. Use of the ICTs (members had to be users).

The choice of time frame regarding the arrival of migrants in Uruguay was due to the inflexion point of the European crisis and the start of the Spanish migratory phenomenon, as it is possible to verify in the records of the Spanish Immigration and Naturalisation Office. The age range corresponds to the sector of the population at working age (Economically Active Population - EPA). The use of ICTs was a crucial variable for this project, since one of its intentions was to analyse the connection maintained by the e-migrants between their country of origin and their country of destination. It was also considered important to observe this phenomenon from the perspective of gender, in order to find if this correlated to any significant variations in the study.

The following table shows more detailed data of the participants of the discussion groups:

\begin{tabular}{|c|c|c|c|c|}
\hline N. Focus Groups & GENDER & AGE & Profession & Time IN URUGuay \\
\hline $\mathrm{FG}_{1}$ & Woman & 27 & $\begin{array}{l}\text { Degree in History with a } \\
\text { master in Gender Studies }\end{array}$ & 4 months \\
\hline $\mathrm{FG}_{1}$ & Man & 43 & Photographer & 4 years \\
\hline $\mathrm{FG}_{1}$ & Woman & 38 & Degree in Communication & 2 years \\
\hline $\mathrm{FG}_{1}$ & Woman & 37 & Sociologist & 3 months \\
\hline $\mathrm{FG}_{2}$ & Man & 39 & Systems Engineer & 1 years \\
\hline $\mathrm{FG}_{2}$ & Woman & 36 & Architect & 2 years \\
\hline $\mathrm{FG}_{2}$ & Man & 33 & Agronomist & 1 year and a half \\
\hline $\mathrm{FG}_{3}$ & Woman & 29 & Journalist & 5 years \\
\hline $\mathrm{FG}_{3}$ & Man & 32 & Architect & 4 months \\
\hline $\mathrm{FG}_{3}$ & Man & 32 & Graphic designer, Architect & 4 months \\
\hline $\mathrm{FG}_{3}$ & Woman & 26 & Degree in Political Science & 4 months \\
\hline
\end{tabular}


From the responses of migrants who completed the questionnaire, the analysis of data obtained from the Spanish Immigration Office databases and the study of focus groups, it was possible to establish the profile of the new Spaniards in Uruguay.

\section{RESULTS}

The study established that distance communication networks are being generated to create new forms of logic and entail collaborative and participatory linking strategies and exchange. Social networks are reticular in structure and significant in number and degree of participation of the e-migrant social actors - that is, those who have the technological resources (it was observed that $96 \%$ of the sample had smartphones). These linking logics can be observed, as already mentioned, in the new flow of Spanish migrants in Uruguay that are part of the virtual platforms "Marea Granate" or "Alianza". From the ICTs and the Internet, these collectives are achieving greater participation, cooperation and horizontal exchange among its members, in order to help and/or denounce the difficult living conditions of some e-migrants (some of the issues the collectives deal with are: where and how to revalidate degrees and academic credentials, how to vote, what happens to social security payments in Spain, precautions with renting a flat etc.). These platforms have different interests but a similar objective: the support, mutual aid and connection between e-migrants.

Concerning the "Alianza" platform, it was possible to observe a genuine desire to generate spaces for the encounter of recent immigrants from Spain and the young descendants of Spaniards who immigrated to Uruguay, in order to help the newly arrived in their social integration:

We are the result of a young people's initiative, a group of young Spaniards and descendants of immigrants from Spain who live in Uruguay. The association encourages the engagement of young Spaniards and descendants in activities related to youth. To this end we created and discovered spaces for integration within the community and encourage the youngsters to take part into those spaces. (Alianza, 2011)

In the "Marea Granate" platform there is a more active participation and discussion of economic policies and their results in Spain:

Corruption, fuelled by an unscrupulous system, both nationally and globally, stole our space and non-existent democracy, our voice. A greedy and sick minority makes decisions that are rightfully ours in it's own exclusive benefit. We denounce the current role of the Troika (EU, ECB and IMF) and the begged vote. (Marea Granate, 2013)

The fact that Spanish migrants, citizens of democratic regimes, analyse and criticize - from a host country, and at a distance - the consequences of economic policies is also part of the game of democracy which transcends national borders. The digital 
and technological revolution plus the globalisation phenomenon have permitted the existence of another type of democratic participation, which was not foreseen by methodological nationalism. The new actors on this stage perform as individuals but are not individualists in the classic neo-liberal sense. Their aim is to create spaces based on friendship, common interests, shared zones and practices; and their interchanges are subjected to a common statute.

This goal is reflected in the "manifest" on the web site of the Spaniards who form the "Marea Granate" group. There, they explain that the organization of their members is horizontal, and that they connect with each other via virtual and presential assemblies with both a local and global reach:

We are a horizontal movement that convenes regularly in assemblies both virtually and in person, both locally and globally. We encourage new forms of participation, self-organisation and the defence of rights which transcend frontiers. For this purpose we are weaving a network of international cooperation, uniting ourselves to other initiatives in order to build a fair future, free from anxiety, be it material, spiritual or in any other form. (Marea Granate, 2013)

The platform "Alianza" also proposes an open form of organisation, divided in commissions, with aims to achieve local and international scope:

The "Alianza..." is a space open to the participation of young people that focuses its activities on the educational, cultural, social and human development aspects. We aim to be both effective and efficient in our organization. We pursue effectiveness and efficiency in our organisation, proposing a working model that involves committees and coordinators, being the tasks and responsibilities distributed among the different working groups. We maintain an interest in Spanish culture and day-to-day life in Spain. (Alianza, 2011)

The majority of the interviewees, that took part in the focus groups, mentioned contacting the members of one or the aforementioned platforms, or both, either while still living in Spain or after moving to Uruguay. Both platforms became references in terms of information and/or collective participation, and, in this communicational process, the contact mediated by the Internet gave rise to offline contact (not mediated by the world wide web) and vice versa. These platforms, thus, have become a virtual and presential articulation between Spain and Uruguay. The activities carried out by these groups produce, transmit and receive symbolic forms (such as significant occasions, manifestos, texts, rituals, etc.) from "here" and "there" in a TCS space that does not belong to either of the countries involved, nor to the media, but is built in the interstitial spaces formed by the e-migrants themselves. Consequently, symbolic forms are configured or reconfigured in a virtual node of social imagery, ideas and news that admits the construction of social scenarios in relation to the participants themselves. 
Traditional mass media (newspapers, TV, radio) had a leading role in forming the mental imagery, the social representations and all the symbolic forms that went into circulation in previous - but recent - historical moments. However, as inferred from the interviews carried out in this study, such configurations and mental images apparently have migrated to the social networks (new cultural forms generated by the Internet) due to the loss of legitimacy of the information provided by traditional mass media. Said loss can also be perceived when it comes to the information transmitted by Spanish institutions and the different Spanish governmental administrations.

These shifts can generate, within governmental organisations, informational fragmentation and also ruptures in the structuring of meanings and symbolic forms that once were used to reach social cohesion, since, nowadays, not everyone has access to the same information at the same time, either through the mass media or through the Spanish government administrations. This happens, firstly, due to the loss of credibility that mass media is experiencing, as mentioned above; said change causes a decrease on the access of individuals to mass media outlets, as we can confirm through the interviewees, who claimed to watch less TV and read less print periodics. Secondly, because the communication strategies to access these new actors and e-migrants, it seems, should be built in line with the new forms of data transmission which have developed from ICTs and the Internet.

In other words, these movements can pose a considerable inconvenience for the Spanish administration at the time of channelling information to e-migrant citizens. These individuals, though delocalised, are still interested in what happens in Spain and wish to participate not only in the Spanish electoral process by voting, but also in the assistance of other e-migrant citizens, by providing quality information about the migratory process.

ICTs can also play an important part in linking all the interested parties by either mediating with state organisations or obtaining solid and truthful information to and from all parties involved (i.e. State entities and the e-migrant community). The social communicational practices of the recent Spanish migrants that are part of the "Marea Granate" or "Alianza..." platforms engendered a process which was on the agenda of the European Council of 2009: the strengthening of e-democracy.

The European Council, based on previous work by other international institutions (United Nations, Organization for Cooperation and Economic Development - OCED -, European Union), recommended that the member states, among other points, consider:

- The use of the opportunities that e-democracy offers to strengthen democracy, democratic institutions, and the democratic process;

- The implementation of e-democracy as the support and strengthener of democracy, democratic institutions and the democratic process. Such practice should happen by the use of the ICTs and should also entail the commitment to the renewed participation of citizens in Democracy (recommendation CM / REC, 2009, p. 4)

The 2009 European Council's recommendations have the ultimate intention of promoting e-democracy from the activities on social networks, thus exploiting the ideas developed by the civil society in the field of electronic democracy: 
Public authorities and representative assemblies should actively seek points of contact with social networking activity dealing with political issues and that are based on the ideas and debates that take place in those new democratic spaces of deliberation and participation. (recommendation CM / Rec, 2009, p.11)

However, collaborative spaces between the administration and citizens do not appear to advance, strengthen nor associate within the guidelines established by the European Union on e-democracy. As some authors point out (Chen et al., 2007; Layne and Lee, 2001), to this date, the idea of e-democracy has not been applied to question what has been done or how to do it, but rather through using the concept and dimension of the ICTs on how to do things more efficiently within the present framework. In other words, e-democracy implements the ICTs in the field of public policy management without including proper strategies nor exploring other alternatives in the decision-making process that manages policies which incorporate the citizens. Also, the pluralism and diversity ideas that follow the logic of an open conception, proposed by the European Council recommendations of 2009, are not being properly considered.

In Latin America electronic government is also seen as a regional challenge. In September 2014, the Electronic Government and Information and Knowledge Society Agency of Uruguay (Agesic) organized the seventh National Meeting of Electronic Government with the participation of Mexico, Argentina, Colombia, and the host country. The concerns of all the participants were: a) the management of technology to ensure it reaches all citizens; b) the generation of a complete inclusion in the territories involved; c) the attainment of a portal for the governments that would function as a multichannel access point for attending to people and their needs; d) the generation of interoperability between government entities; e) the incorporation of the public into the services rendered by the government.

Nevertheless, we understand that the debate should not be just technical, since this issue isn't centred only on the adaptation of e-democracy to a residual form of political democracy. The substantial problem is to clarify whether the technological changes will be incorporated by the public authorities in order to promote and participate in the activities on the social networks, with a view to fully exploit e-democracy. This could be achieved, for instance, through the incorporation of the discussions, exchanges, and participatory proposals generated in multiple civic platforms created by migrants that belong to Latin American and European democracies. In other words, can we assume that the intervention of ICTs will change the ways of working of representative institutions and public administrations? On this regard, several authors (Abramson \& Morin, 2003; Bimber, 1999; Gronlund, 2002; Margetts, 2009) showed, through many examples, how ICTs actually improves relations between citizens and administrations.

There are, however, specialists who claim that the relationship between the ICTs and public policies and services will not change the technocratic and vertical logic that was consolidated during the twentieth century. According to those who hold this opinion, 
the contrary is more likely to happen: the use of the ICTs could reinforce the control and the authority of the institutional elite rather than enhance the capacity for intervention of the citizens (Hindman, 2009). Examples that support this view are the policies for the control of the movement of people developed by the European Union, such as the massive digitalised register of immigrants in the Schengen Information System (SIS) and the Eurodac and European Identification System (VIS). These systems are aimed at visualising the flow of migrants, identifying risk categories within the immigrant flows and undermining their legal situation (Bolludanski \& Ciapello, 2002).

In short, the digital revolution would have a dual role: on one hand it could reinforce the capabilities of big institutions and organisations to control and watch over whole societies; and, on the other hand, it has the potential to stimulate and encourage new capacities in individuals and groups and to help them develop critical thinking, coordination, innovation and the ability to propose concrete alternatives to the issues that may arise.

Having what was just said in mind, we insist that the main issue here is not how technology helps (or not) in the healthy implementation of public policies by widening the participation of e-migrants, but rather how public policies efficiently incorporate mechanisms of participation in order to ensure the conditions for the inclusion of different new actors, providing, in this way, more efficient solutions, legitimised and accepted by the general population.

ICTs are an important tool, but they are not sufficient on their own. They need to be used in simultaneity with a real interest and will of government administrations to collectively promote the participation of citizens at all levels, in order for them to recognize differences, to debate, to foment the interchange of opinions - all aspects that must perforce precede the agreements and disagreements which in turn produce the vision or visions of what we want as a society (Nieto Enrione, 2010).

These ideas do not propose to legitimise a process of "direct democracy", in which the new actors of a society sit at their computers making decisions that have an impact on the lives of common citizens. Neither do they imply that the ICTs have the power to completely renovate the political sphere nor supersede the "old" forms of representation by the direct expression of the will of the citizen through the network platforms used to enunciate their opinions. As Martin Barbero (2007, p. 19) suggests, this would imply falling into the trap of the immediacy and transparency of the "cybernetic webs", which explodes the very foundations of what is "public" as it is generally perceived: processes of liberation and criticism. A dangerous trap, as this would or could strengthen the belief that the individual can connect and communicate his ideas without any social mediation. This would increase the lack of trust in any form of delegation and representation in present power structures.

Lastly, it should be noted that in the co-definition of the participatory engineering the design of the appropriate instruments is crossed by symbolic dimensions that affect those actions, and that are determinant in the construction and transmission of certain visions of the social order (Diaz-Tendero, 2010). Under this supposition, public policies and their resulting actions are understood as a place where "citizenship spaces" can be 
constructed, since the groups involved in such development gain, while doing so, a form of social existence or visibility (Duchesne \& Muller, 2003). The real problem then lies in the following question: is public policy made jointly with the citizenry in a new "Technological, Geographical and Social" space? (Olivera et al, 2014; Olivera, \& Vancea, 2013a, 2013b; Olivera, 2013a; 2013b; Olivera, 2011).

TGS spaces can transform the process of formation, elaboration, decision-making, implementation and evaluation of public policy by the presence and intervention of new participants, such as the e-migrants. These social actors incorporate other forms of relationship - outside the traditional mechanisms of political participation - and utilise diverse resources that act as catalysts and influence the process of participation and interchange. As Subirats (2013, p. 69) writes: we are in the presence of "moments of collective aggregation on the web" without stable and defined interlocutors. The strength of these 'actors' does not reside in the number of people they represent but rather in their capacity to interconnect and to set the public agenda by the pressure exerted by the public within and without virtual space. Hence, the challenge will be understanding in what way the TGS spaces, which are made up by the e-migrants, can affect the intermediation and interaction of political institutions with the public and the depth of the changes they could generate in the different roles and forms of relating.

The challenge of governments, in this context of increasingly complex communication, is to understand the new ways of relating and the referential processes that are woven together in the TGS spaces. In order to understand them, it seems essential to take into account a plural perspective and to consider the structural axis of cultural identity, the global interconnection and a multidimensional policy.

As Castells (2004) explains, in a final analysis, what the technological revolution introduces in our societies is not so much an enormous number of new machines but rather a new form of relationship between symbolic processes - which are cultural and the forms of production and distribution of goods and services. TGS spaces do not refer solely to ICTs but to new forms of perception and language, in other words, to new technosociabilities.

\section{Discussion}

The understanding of the new types of relationship between states and citizens, within the study of traditional forms of political participation, public decision-making and present day migratory processes, can require a different focus: a new perspective that allows an escape from established methodologies, from the way of defining the object of study and from the formulation of investigative questions and that leads to the review of concepts and analytical tools used for the analysis of the migratory phenomena within the Information Society and in the framework of the new TGS spaces.

The new e-migrant actors who transit the TGS spaces introduced a greater complexity to the analysis and understanding of what happens with the practices of participation, socio-political involvement and the construction of citizenship. These actors participate, 
occupy, mediate, invade, renew, question and subvert the traditional forms of political participation and decision-making of the public offices, demanding recognition and not to any extent the representation of the migrant collective "per se".

E-migrants construct human, civic and cyberdemocratic networks, which circulate in new common spaces that break the boundaries and borders of citizenship (internalexternal, local-global, public-private), pointing to new cultural agendas of organisation, sociability and exchange of information (online-offline), in a geographical space of identity and virtual and presential participation (being said participation political, cultural, social etc.). These new actors, perhaps product of the $15 \mathrm{M}$ experience in Spain, address information, communication, culture and politics with greater rigor and in a more systematic manner.

In other words, as Sierra explains (2006), as long as cyberdemocracy projects a new stage or public space (new methods and democratic options for the active participation of the citizenry, and above all a new conception of the space and mediation with the active intervention of the citizenry) public policy must endeavour to rationally respond to this emerging "new reality". It is necessary to question, moreover, the very notion of citizenship and the participation in the state within a legal and social framework that entails the necessary conditions of legality and stability in the context of the transition from the nation state to the fluid state that predates cognitive capitalism. The participation of groups such as "Marea Granate" and "Alianza" implies more depth in the significance and representation of mediations and distances, social and cultural practices and the cognitive frameworks of reflection and political imagination.

It should be noted that the reticular map of identity, configured in the TGS spaces, does not necessarily coincide with political-administrative territories, with what is known as methodological nationalism. These new maps encompass citizens of Madrid, Seville, Barcelona, Basques etc. and do not necessarily fragment them into regional associations or entities, as occurred in past migrations. In this new cartography a generational rupture can be seen: the old and new Spanish migrants in Uruguay cannot understand each other. Their interests, social practices and subjectivities are strongly differentiated. The TGS spaces, such as "Marea Granate" or "Alianza", are made up of individuals from diverse regions of Spain.

"Marea Granate" or "Alianza" are the sum of identities of those who live with their social capital alive and present. In order to understand these new spaces in their deepest essence we must understand that the construction of citizenship entails the deconstruction of it's meaning; it involves the subversion of assumptions, the violation of the tranquillity of the term, of its daily routines and the contamination of the concept with its own instability.

The concept of the e-migrant, then, brings a series of questions: what kind of participation does our democracy require? Can we speak of e-citizenship as a new concept and social form? How to think the use of ICTs to enhance citizens' involvement and participation processes? Is it possible to form skills and capabilities to be used by normal, everyday citizens? What roles are played by the social platforms generated from the 
paradigm of creation and circulation of content where the public user can engage actively in the process?

The challenge of public policy is to enhance, channel, mediate and communicate for the development of active citizenship through the use of the new TGS spaces. It is also to evaluate and define participation in order to obtain a radical and plural democracy. Perhaps, as Sierra (2006) indicates, it is necessary to transcend the traditional definition of culture imprinted in the management by international development policies, according to which, culture is seen as resource, storage, distribution and organisation of the access to symbolic goods according to the conditions of circulation and the transnational valuation of capitalism. Classical forms of political participation should be renewed and this entails the radical reformulation of the precepts of representative democracy by decentralising the information systems and the public decision-making process, beyond the organisational models that are based on the efficient rationality of the informational paradigm.

Summing up, the technical problems of access, circulation and/or rapid and safe transmission of data on the Internet are substantial, but it is more urgent to think about the configuration of the web as a TCS space for the citizenry, in the widest sense. The disappearance of both the external and internal limits of cities and territories, as well as the integration between public and private spheres, not only lead to new cultural agendas of organisation and technosociabilities, but also to the creation of another space of identity and political participation, deeply connected to the various electronic forms of interaction and informational exchange. In short, we are witnessing, nowadays, the rise of a different form of identity and of political participation.

\section{REFERENCES}

Abramson, M. A. \& Therese L. (Eds) (2003). E-Government 2003. Oxford: Rowman \& Littlefield.

Becerra, M. (2003). Sociedad de la información: proyecto, convergencia, divergencia. Col. Enciclopedia Latinoamericana de Sociocultura y Comunicación. Buenos Aires: Norma.

Alianza- Movimento (2011). Retrieved from https://www.linkedin.com/groups/ ALIANZA-J\%C3\%B3venes-Espa\%C3\%Bioles-Descendientes-Uruguay-4240829/about.

Beck, U. (2003). Toward a new critical theory with a cosmopolitan intent. Constellations, 10, 453-468.

Beck, U. (2006). The cosmopolitan vision. Cambridge: Polity.

Beck, U. \& Sznaider. N. (2006). Unpacking cosmopolitanism for the social sciences: A research agenda. British Journal of Sociology, 57, 1-23.

Beck, U. \& Grande, E. (2010). Varieties of second modernity: The "cosmopolitan turn" in social and political theory and research. British Journal of Sociology, 61, 409-443.

Benhabib, S. (2004). The rights of others: Aliens, residents and citizens. Cambridge: Cambridge University Press. 
Bernal, P. (2004, outubro). La interfaz: un dispositivo de comunicación para posibilitar la interacción entre las comunidades. Comunicacão apresentada no VII Congreso Latinoamericano de Ciências da Comunicação, Argentina.

Bimber, B. (1999). The Internet and citizen communication with Government: Does the medium matter?. Political Communication, 16(4), 409-428.

Boltanski, L. \& Chiapello, E. (2002). El nuevo espíritu del capitalismo. Madrid: Akal.

Castells, M. (2004). La era de la Información, economía, sociedad y cultura, Vol. 1 La sociedad red. México: Siglo XXI.

Chang, K.S. (2010). The second modern condition? Compressed modernity as internalized reflexive cosmopolitization. British Journal of Sociology, 61, 444-464.

Chen, H. Brandt, B., Gregg, V., Traunmueller, R., Dawes, S. Hovy, E. Macintosh, A. \& Larson, C. (Eds.) (2007), Digital government: E-Government research, case studies, and implementation. Nova York: Springer.

Comité de Ministros (2009). Recomendación cm/rec (2009). 1 del Comité de Ministros a los Estados miembros sobre la democracia electrónica (e-democracia). Adoptada por el Comité de Ministros el 18 de febrero 2009 en la reunión del 1049a Delegados de Ministros). Retrieved From http://www.coe.int/t/dgap/ democracy/Activities/GGIS/CAHDE/2009/RecCM2009_1_and_Accomp_Docs/Recommendation\%20 CM_Rec_2009_1E_FINAL_PDF.pdf.

Cruz, M. T. (2007). Espaço, media e experiência. Na era do espaço virtual e do tempo real. Comunicação $e$ Sociedade, 12, 23-27.

Danolo, D. (2009). Triangulación: Procedimiento incorporado a nuevas metodologías de investigación. Revista Unam 10, 8. Retrieved from http://www.revista.unam.mx/vol.10/num8/art53/art53.pdf.

De Kerckhove, D. (2005). Los sesgos de la electricidad. Lección inaugural del curso académico 2005-2006 de la UOC. Retrieved From http://www.uoc.edu/inauguralo5/esp/kerckhove.pdf.

Díaz-Tendero, E. (2010). Matriz de acción estatal e intereses ciudadanos ¿Qué puentes tenemos?. Le Monde diplomatique. Retrieved from http://franceamsud.org/site/images/stories/pdf/publicaciones/96Democracia-elec.pdf.

Diminescu, D. (2008). The connected migrant: an epistemological Manifesto. Social Science Information, 47 (4), 565-579.

Duchesne, S. \& Muller, P. (2003). Représentations croisées de l'État et des citoyens. In Pierre Favre, Yves Schemeil \& Jack Hayward (Eds.). Être Gouverné: Études en L'Honneur de Jean Leca (pp. 35-51). Paris: Presses de Sciences Po.

Escobar, A. (2000). Welcome to cyberia: notes on the anthropolgy of cyber cultura. In David Bell\&Barbara M. Kennedy (Eds.), The Cybercultures Reader (pp. 56-76). London and New York: Routledge.

Finquelievich, S. (2000). ¡Ciudadanos a la red! Los vínculos sociales en el ciberespacio. Buenos Aires: Ciccus/La Crujía.

Georgiou, M. (2010). Identity, space and the media: Thinking through diaspora. Revue Européenne des Migrations Internationales, 26(1),17-35.

Gómez, E. (2003). Cibersexo ¿la última frontera del eros? Un estudio etnográfico. México: Universidad de Colima.

Graham, St. \& Marvin, S. (2001). Splintering urbanism. Londres: Routledge. 
Gronlund, A., ED., (2002). Electronic government: Design, applications and management. Londres: Idea Group Publishing.

Hindman, M. (2009). The myth of digital democracy. Princeton: Princeton University Press.

Kroes, R. (2000). Ciudadanía y globalización. Valencia: Cátedra.

Layne, K. \& Lee, J. (2001). Developing fully functional e-government: A four stage model. Government Information Quarterly, 18(2),122-136.

Maharaj, S. (2010). Small change of the universal: Beyond modernity? British Journal of Sociology, 61, 565-578.

Marea Granate (2013). Manifiesto. Retrieved From http://mareagranate.org/.

Margetts, H. (2009). Public management change and e-Government: The Emergence of digital era governance", In Chadwick, A. \& Howard (Eds.), The Handbook of internet Politic (pp. 114-128). Londres: Routledge.

Martín Barbero, J. (2007). Tecnicidades. Identidades, alteridades, des-ubicaciones y opacidades de la comunicación en el nuevo siglo. Diálogos de la Comunicación. Retrieved From http://www.olavarria.com/ ciudad/universitarios/biblioteca/descargas/b/martin_barberoı.pdf.

Mattelart, A. (2003). Geopolítica de la cultura. Bogota: Desde Abajo.

Mattelart, A. (2007). Historia de la sociedad de la información. Barcelona: Paidós.

Molina, J. L. (2001). El análisis de redes sociales: una introducción. Barcelona: Bellaterra.

Nedelcu, M. (2009). Le migrant online. nouveaux modèles migratoires à l'ere du numérique. Paris: L' Harmattan.

Nieto Enrione, M. (2010). El doble click a la democracia electrónica: refocalizando las visiones en Democracia Electrónica ¿Qué desafíos para América Latina? Le Monde Diplomatique, 49-51. Retrieved from http://franceamsud.org/site/images/stories/pdf/publicaciones/96-Democracia-elec.pdf.

Olivera, M.; Lema, F.; Morales, MJ.; Simon, E. \& Ferreira, T. (2014). Estudio de los movimientos migratorios recientes de España a Uruguay. Nuevos espacios tecnológicos, geográficos y sociales de vinculación. Montevideo, Uruguai: Fundación Polo Mercosur y Dirección General de Migraciones de España.

Olivera, M. N. (2011). E-migración. Las TIC como herramienta de gestión de las políticas de inmigración en Cataluña, Dissertação de Doutoramento, Universidade Autónoma de Barcelona, Barcelona, Espanha. Retrieved From https://www.educacion.gob.es/teseo/mostrarRef.do?ref=944310.

Olivera, M. N. \& Vancea, M. (2013). E-migrant women in Catalonia: Mobile phone use and maintenance of family. International Journal of journal, Gender, Technology and Development, 17, 179-203.

Olivera, M. N. (2013a). E-migración: las TIC como herramienta de gestión de las políticas de inmigración en Cataluña. Revista Eletronica Eptic On Line.Retrieved From http://dialnet.unirioja.es/servlet/ articulo? codigo $=4253519$.

Olivera, M. N. (2013b). La e-migración: un nuevo espacio para pensar la retórica de la integración en las políticas migratorias. Revista Científica en Comunicación y Nuevas Tecnologías. ICONO, 14, 233-251.

Olivera, M. N. (2013C). "E-Migration: a new configuration of technological, geographical and social spaces. International Journal of e-PoliTIC (IJEP), 4, 18-31.

Olivera, M. N. (2014). E-migración ¿Nuevos actores, espacios y políticas?. ODISEA-Revista de Estudios Migratorios, 1, 1-21. 
Olivera, M. N., Lema, F. \& Dávals O 'Neil, C. (2014). Redes transnacionales: Red Uruguay Encuentro. Nuevo espacio tecnológico, geográfico y social. Revista de Ciencias Sociales, 26 (33), 121-136.

Portes, A.; Guarnizo, L. \& Patricia L. (1999). The study of transnationalism: pitfalls and promise of an emergent research field. Ethnic and Racial Studies, 22 (2), 217-337.

Rheingold, H. (1996). La comunidad virtual. Barcelona: Gedisa.

Schnapper, D. (2001). De l'etat-nation au monde transnational. Du sens et de l'utilité du concept de diaspora. Revue Europeéenne des Migrations Internationales, 17 (2), 9-36.

Sierra, F (2006). Final report: New information technologies, participation and active citizenship. Retrieved From http://pt.slideshare.net/FranciscoSierraCaballero/sierra-for-servaes.

Subirats, J. (2013). Internet y participación política. Nuevos actores?, nuevos desafíos? Revista de Ciencias Sociales, 26 (33), 55-72.

Tremblay, G. (2003). La sociedad de la información y la nueva economía. Promesas, realidades y faltas de un modelo ideológico. Telos, 54, 16-23.

Vertovec, S. (1999). Conceiving and researching transnationalism. Ethnic and Racial Studies, 22 (2), 447-62.

Vertovec, S. (2009). Transnationalism. London and New York: Routledge.

Webster, F. (2006).La sociedad de la información revisitada. Biblioteca Universitaria, 9,22-44.

Translation into English by Flávia Serafim

\section{BiograPHICAL NOTE}

Mauricio Nihil Olivera is titular professor at the University of the Republic, in Uruguay. His research interests relate to new comunnicative realities, spaces of civic intermediation as its forms of organization and vinculation, within the context of the Information Society, also considering internet intervention, as well as tecnologies of information and communication.

E-mail: mauricio.nihil@fic.edu.uy

Universidade da República, Instituto de Comunicação, Calle José Leguizamón 3666, Montevideo, Uruguay

* Submitted: 18-06-2015

* Accepted: 21-07-2015 